\title{
Сергій КИРИЛЕНКО
}

\section{КАІСНТООРІСНТОВАНІ ПІДХОДИ У РОЗДРІБНОМУ БАНКІВСЬКОМУ КРЕДИТУВАННІ}

Узагальнено сучасні тенденції роздрібного кредитування українськими банками, відзначено позитивні зміни, які відбулися за останні роки у кредитуванні фрізичних осіб. Зроблено акцент на важливості клієнтоорієнтованого банківського обслуговування. Виявлено елементи клієнтоорієнтованих підходів у споживчому кредитуванні, кредитуванні готівкою, авто- та іпотечному кредитуванні, у застосуванні банками партнерських програм. Зазначено основні перешкоди для подальшого розвитку роздрібного кредитування, обгрунтувано напрямки активізації роздрібного банківського кредитування.

Ключові слова: роздрібне банківське кредитування, банківський маркетинг, клієнтоорієнтоване банківське обслуговування.

\section{Сергей КИРИЛЕНКО}

Клиентоориентированные подходы в розничном банковском кредитовании

Обобщены современные тенденции розничного кредитования украинскими банками, отмечены положительные изменения, которые произошли в течении последних лет в кредитовании фризических лиц. Сделано акцент на важности клиентоориентированного банковского обслуживания. Выявлено элементы клиентоориентированных подходов в потребительском кредитовании, кредитовании наличными, авто- и ипотечном кредитовании, при использовании банками партнерских программ. Отмечено основные препятствия для дальнейшего развития розничного кредитования, обоснованы направления активизации розничного банковского кредитования.

Ключевые слова: розничное банковское кредитование, банковский маркетине, клиентоориентированное банковское обслуживание.

\section{Serhiy KYRYLENKO}

\section{Client-oriented approaches in retail bank lending}

Introduction. Crisis phenomena in the Ukrainian economy negatively affected the consumer market, caused a decrease in the population's demand for credit products of banks. However, over the past two years, an increase in the retail lending portfolio has taken place, which is evidence of a certain improvement in the socio-economic situation, the improvement of the banking system, the growth of income of citizens and the restoration of their confidence in

() Сергій Кириленко, 2017 
banks. In such conditions, the task is to consolidate positive trends in retail lending, including by applying client-oriented approaches to banking.

Purpose. The purpose of the article is to summarize the current practice of retail lending by Ukrainian banks, identify elements of client-oriented approaches in retail lending and substantiate ways to improve them.

Results. The practice is analyzed and tendencies of retail lending in Ukraine are identified, the main problems that hinder its development are identified. The emphasis is on the positive impact on retail lending of the Law of Ukraine "On Consumer Lending". The elements of application of client-oriented approaches in retail lending are generalized.

Conclusions. The article substantiates the conclusion on how to improve client-oriented approaches in retail lending: taking into account the needs of clients in full measure; improvement of banking services; development of remote sales channels; simplification of lending conditions; increasing customer loyalty; application of stimulating tools; ensuring the availability and transparency of banks; distribution of affiliate programs for lending.

Keywords: debt finance, capital financing, linear programming, local borrowing, financial capacity.

JEL Classification: G210, M310.

Постановка проблеми. Кризові явища, які мали місце в економіці нашої країни, негативно вплинули на споживчий ринок, спричинили інфляцію і зменшення реальних доходів громадян, що, в свою чергу, призвело до відтоку заощаджень з банківської системи, зниження попиту населення на кредитні продукти. Проте слід враховувати, що споживчий ринок $є$ рушійною силою динамічного розвитку кожної країни, адже його стан відображає зміни у рівнях добробуту громадян, впливає на виробництво товарів, робіт і послуг, забезпечує притік коштів у банки, стимулює споживче кредитування.

Протягом останніх років відбулося зменшення попиту на банківські кредити та падіння обсягів банківського кредитування, яке у 2016 р. повернулося лише до рівня 2009-2010 років. Разом з тим кредитування належить до базових банківських продуктів, а саме активних операцій, і відіграє важливу роль у функціонуванні банків. Кредитні операції становлять головну характе- ристику банку саме як кредитної установи; вони приносять банкам основну частину прибутку. Тому проблеми активізації кредитної діяльності банків набувають особливої актуальності у посткризовий період, що вимагає зміни підходів до ії̈ здійснення, зокрема у сорері кредитування фізичних осіб.

Аналіз останніх досліджень і публікацій. Питанню банківського кредитування присвятили свої праці багато українських вчених, зокрема: О. Дзюблюк, В. Міщенко, А. Мороз, М. Савлук, Н. Шелудько та ін. Маркетингові аспекти банківського кредитування досліджують такі вітчизняні науковці, як О. Вовчак, О. Дима, О. Колодізєв, І. Лютий, С. Назлуханян, О. Солодка, Н. Тарасевич, В. Ткачук, Н. Ткачук та ін. Значний науковий інтерес становлять обґрунтовані у зарубіжній літературі теоретичні та практичні положення щодо кредитування фрізичних осіб, зокрема в працях науковців пострадянського простору.

Разом з цим необхідність динамічного розвитку роздрібного банківського креди- 
тування в Україні в умовах виходу економіки з кризи, потреба у зміцненні лояльності клієнтів та збільшенні клієнтської бази вимагають проведення подальших пошуків в напряму узагальнення досвіду роздрібного кредитування, застосування клієнтоорієнтованих підходів у його здійсненні й обґрунтування перспективних шляхів щодо покращення банківського обслуговування.

Метою статті $€$ узагальнення сучасної практики роздрібного кредитування українськими банками, виявлення елементів клієнтоорієнтованих підходів у роздрібному кредитуванні й обґрунтування шляхів їх вдосконалення.

Виклад основного матеріалу дослідження. Нині в структурі банківських кредитів українських банків 16\% від загальної суми кредитів припадає на роздрібне кредитування, тобто на кредити фрізичним особам. Слід зазначити, що протягом 2016 р. відбулося зменшення портфеля роздрібного кредитування з 181,7 до 157,4 млрд грн, і лише у 2017 р. спостерігається поступове збільшення кредитування фрізичних осіб, яке станом на 1.11.2017 р. досягло 160,8 млрд грн [1]. Найбільш розповсюдженими видами кредитів, які надають фрізичним особам, є споживчі кредити, автокредити й іпотечні кредити. Основними цілями відкриття кредитів громадянами є: оплата щоденних потреб, купівля побутової техніки, ремонт квартири або будинку, лікування, придбання енергозберігаючого обладнання і матеріалів, купівля нерухомості [2, с. 29]. Понад $55 \%$ кредитів населенню було надано у національній валюті. Залежно від терміну кредитування 28,3\% суми усіх роздрібних кредитів становлять кредити на строк до 1 року, 21,4\% - від 1 до 5 років і $50,3 \%$ - понад 5 років [3, с. 7-8].

Позитивні зрушення у кредитуванні фізичних осіб стали свідченням певного покращення соціально-економічного ста- новища в країні, оздоровлення банківської системи, зростання доходів громадян та відновлення їх довіри до банків. Так, зріс попит на беззаставні, готівкові кредити та кредитні картки. Зазначені види кредитів високоприбуткові для банків і тому конкуренція на ринку без заставного кредитування збільшується, що спонукає банки до спрощення умов кредитування з метою залучення додаткових клієнтів.

У 2016-2017 рр. зросли загальні обсяги наданих споживчих кредитів, причому збільшуються терміни кредитування і кількість банків, які надають споживчі кредити. Банки зменшили процентні ставки та полегшили вимоги до позичальників, проте загалом умови споживчого кредитування суттєво не змінилися. Достатньо великим попитом користуються кредити на придбання товарів у торгових мережах завдяки швидкості надання та нульовій розстрочці. Крім того, українські банки надають безвідсоткові періоди на використання кредитного ліміту для покупок у торгових мережах, а також послуги cashback - повернення частини використаних клієнтом коштів на його картковий рахунок (3-5\% витрачених сум). Широкою популярністю користуються кредитні картки, які мають прості умови щодо їх одержання. Використання карток передбачає відновлення кредитної лінії після погашення кредиту, що створює додаткові зручності для клієнтів.

Слід зазначити, що на динаміку споживчого кредитування позитивний вплив має набуття чинності у 2017 р. Закону України “Про споживче кредитування", який визначив правові й організаційні засади споживчого кредитування. Закон спрямований на захист прав та інтересів споживачів і кредитодавців, створення конкурентного середовища на ринках фінансових послуг та підвищення довіри до нього, забезпечення сприятливих умов для розвитку економіки, 
гармонізацію українського законодавства з міжнародними стандартами. Важливими нормами закону $є$ визначення складу стандартної інформації про споживчий кредит, яка має містити: максимальну суму, на яку може бути виданий кредит; реальну річну процентну ставку; максимальний строк, на який видається кредит; у разі надання кредиту для придбання товарів (послуг) у формі оплати з відстроченням або з розстроченням платежу - розмір першого внеску. В законі визначено, що стандартна інформація має бути зрозумілою і точною; у рекламі забороняється зазначати, що споживчий кредит може надаватися без документального підтвердження кредитоспроможності позичальника або що кредит є безпроцентним чи надається під нуль процентів [4].

Одним із розповсюджених видів споживчих кредитів $€$ кредити готівкою. Протягом останніх двох років в окремих банках покращилися умови кредитування готівкою, зокрема було підвищено граничний вік позичальників, що зумовлено високою конкуренцією серед банків за заможних позичальників. Як відомо, сегмент заможних позичальників - це люди старшого віку. Проте ставки за готівковими кредитами є вищими, порівняно з іншими видами кредитів, внаслідок наявності високих ризиків щодо їх неповернення.

Але далеко не всі банки здійснюють кредитування готівкою. Так, станом на травень 2017 р. лише половина з 40 найбільших банків України надавали кредити готівкою фрізичним особам. Незважаючи на планомірне зниження облікової ставки НБУ і ставок за депозитами, середня вартість кредитів під заставу за останній рік зросла більш ніж на 5 в.п. При цьому кількість банків, що надають такі кредити, залишається стабільною [5].

Згідно з моніторингом, який проводить Prostobank.ua, ставки кредитування готів- кою залежать від терміну кредитування, таким чином:

- для кредитів на 5 років середня ефрективна ставка (номінальна ставка, скоригована з урахуванням одноразової і щомісячної комісії, страховки при їх наявності) становить $64,28 \%$ річних. Такі кредити надають лише 7 банків;

- для кредитів на 3 роки середня ефективна ставка - 79,19\% річних (20 банків за 130 програмами кредитування);

- для кредитів на 2 роки середня ефективна ставка - 82,09\% річних (20 банків за 131 програмою кредитування);

- для кредитів на 1 рік середня ефективна ставка - 83,38\% річних (20 банків за 124 програмами кредитування) [5].

Найбільшим попитом користуються: кредити на короткий термін, зокрема овердрафти на зарплатні картки, за якими банки встановлюють понижені ставки для "своїх" клієнтів; кредитні картки з пільговим періодом, які дають можливість користуватися за невелику плату коштами банку за умови своєчасного повернення коштів. Основними формами надання кредитів фрізичним особам є: відкриття кредитних ліній на нову або існуючу картку; перерахування коштів на рахунок магазину, де купується товар; одноразове зарахування коштів на картковий рахунок; видача готівки.

Як застава у споживчому кредитуванні готівкою переважно використовується нерухомість, автомобілі, товари тривалого використання, золото та ювелірні вироби, земельні ділянки, причому як ті, що купують, так й інші, які $є$ у власності позичальника, а також банківські депозити.

В табл. 1 подано інформацію щодо основних умов за кредитами під заставу нерухомості (по одній кредитній програмі з найменшою ставкою) від банків, які належать до 50 великих роздрібних банків України. 
Програми кредитування під заставу нерухомості в банках України, станом на 15.02.2017 р.*

\begin{tabular}{|c|c|c|c|c|}
\hline Банк & Назва програми & $\begin{array}{c}\text { Аванс } \\
\text { (мін.), \% }\end{array}$ & $\begin{array}{c}\text { Строк } \\
\text { кредиту } \\
\text { (років) }\end{array}$ & $\begin{array}{c}\text { Мінімальна } \\
\text { ефективна } \\
\text { ставка, \% }\end{array}$ \\
\hline $\begin{array}{l}\text { "VS Bank } \\
\text { (Фольксбанк)" }\end{array}$ & $\begin{array}{l}\text { Акційні умови за кредитами під заставу } \\
\text { нерухомості (плаваюча ставка з 4-го року) }\end{array}$ & 30 & $\begin{array}{l}10,1,2 \\
5,7\end{array}$ & 18,36 \\
\hline “Кредобанк” & Під заставу нерухомості & 40 & 1 & 20,22 \\
\hline "МАРФІН БАНК" & $\begin{array}{l}\text { Кредити під інші потреби із забезпеченням } \\
\text { у вигляді іншої застави }\end{array}$ & 30 & $\begin{array}{c}10,1,2 \\
5,7\end{array}$ & 22,59 \\
\hline “Ощадбанк” & Кредит під заставу нерухомості & 30 & $\begin{array}{l}10,15,1 \\
20,2,5,7\end{array}$ & 23,47 \\
\hline $\begin{array}{l}\text { "Укрсоцбанк } \\
\text { (UniCredit Bank)" }\end{array}$ & $\begin{array}{l}\text { Кредит під заставу нерухомого майна без страху- } \\
\text { вання життя (плаваюча ставка з 4-го року) }\end{array}$ & 40 & $\begin{array}{c}10,1,2 \\
5,7\end{array}$ & 24,12 \\
\hline “ТАСКОМБАНК” & Кредит під заставу нерухомості ануїтет & 50 & $\begin{array}{l}10,1,2 \\
5,7\end{array}$ & 24,66 \\
\hline “Львів" & Під прийнятну заставу (нерухомість) & 30 & $\begin{array}{l}10,1,2 \\
5,7\end{array}$ & 25,57 \\
\hline “ОТП Банк” & $\begin{array}{l}\text { Кредит під заставу нерухомості (плаваюча став- } \\
\text { ка з 13-го місяця) }\end{array}$ & 50 & $\begin{array}{l}10,1,2 \\
5,7\end{array}$ & 27,24 \\
\hline “БТА Банк” & Під заставу нерухомості & 30 & $\begin{array}{c}10,1,2 \\
5,7 \\
\end{array}$ & 27,5 \\
\hline “Південний” & “Південна мрія” & 50 & 1,2 & 29,34 \\
\hline “Мегабанк” & Кредит під заставу нерухомості & 50 & $\begin{array}{c}10,1,2 \\
5,7 \\
\end{array}$ & 31,1 \\
\hline “Полтава-банк” & $\begin{array}{l}\text { Споживчий кредит під заставу нерухомості, авто- } \\
\text { мобіля }\end{array}$ & 50 & $1,2,5,7$ & 62,03 \\
\hline
\end{tabular}

* Складено на основі [5].

Як бачимо з табл. 1, кредити під заставу нерухомості надаються на строк від 1 до 20 років з умовою внесення авансового платежу в розмірі $30 \%, 40 \%$ або 50\% від суми кредиту, мають надзвичайно широкий діапазон мінімальної ефективної ставки від 18,36\% річних у “Фольксбанку" до 62,03\% річних у "Полтава-банку". Слід зазначити, що надання заставних кредитів певною мірою зменшує банківські ризики, хоча загалом цей вид кредитування залишається достатньо ризиковим. В контексті розвитку клієнтоорієнтованості при надання таких кредитів актуальним видається застосування індивідуальних підходів у кредитуванні постійних клієнтів, особливо 3 позитивною кредитною історією.
Позитивною тенденцією роздрібного банківського бізнесу $є$ пожвавлення на ринку автокредитування, хоча загалом попит на автомобілі набагато менший внаслідок девальвації національної валюти. Якщо у 2015 р. відбулося двократне зменшення продажів автомобілів, то у 2016 р. спостерігалося збільшення продажів на 40\% і досягло 65,56 тис. одиниць. Частка продажів авто в кредит становила 18\% від загальної кількості проданих автомобілів [6, с. 29]. Збільшується інтерес 3 боку клієнтів на кредити для придбання вживаних автомобілів. Поява такого виду авто кредитів спричинена, на жаль, низьким рівнем доходів значної частини населення та недостатнім платоспроможним попитом. 
Трендом останніх років $є$ запровадження банками партнерських кредитних програм з автодилерами, згідно з якими позичальники можуть одержати найбільш вигідні умови, зокрема низьку ставку, за звичайними програмами ставки становлять 30-35\%. Обов'язковою умовою кредитування в межах партнерських програм є початковий внесок у розмірі $10 \%$ вартості автомобіля. Чим вищий платіж, тим більш вигідні пропонуються умови кредитування. Прикладами партнерських $є$ спільні програми "ОПТ Банку" з Hyundai Finance, банку “Глобус" з великими дилерами “Укравто”, “АиС”, “Богдан”, “Єврокар”, ПАТ “Креді Агріколь Банк” тощо.

Набуває поширення кредитування заходів із підвищення енергоефективності, що зумовлено постійним зростанням комунальних тарифів. Наприклад, "Ощадбанк" пропонує так звані “теплі" кредити на проведення енергоефективних заходів в окремій квартирі, у приватному будинку, в багатоквартирних будинках, а сума таких кредитів за 2014-2016 рр. перевищила 2 млрд грн, було надано 130 тисяч кредитів на утеплення житла [6, с. 29]. Держава і місцева влада стимулює надання кредитів із підвищення енергоефективності шляхом компенсації частини суми позики. Активно застосовується таке кредитування в іншому державному банку - "Укргазбанку".

Вперше за останні роки у 2016 р. відбулося пожвавлення на ринку іпотечного кредитування, хоча загалом ставки за такими кредитами залишаються достатньо високими. Збільшення попиту на іпотечні кредити обумовлено як зростанням доходів окремих груп населення, так і збільшенням попиту на покращення умов проживання. Іпотечні позики у 2017 р. видають лише 12 банків, хоча такі програми кредитування $\epsilon$ і в деяких інших банках.

У табл. 2 подано дані щодо основних умов іпотечного кредитування у 10 бан- ках-переможцях щорічного рейтингу, який складає Financial Club. В зазначених банках найбільша кількість клієнтів скористалися іпотечними кредитами. Як видно з даних табл. 2, умови іпотечного кредитування в цих банків суттєво відрізняються. Так, середньорічна ефективна ставка коливається в діапазоні від 19,60\% до 30,47\%, разова комісія при видачі кредиту лише у "Кредобанку" не стягується, а в інших банках може становити 1,00-2,50\% від суми кредиту. Додаткові видатки при видачі іпотечного кредиту пов'язані з обов'язковим страхуванням застави, життя, від нещасного випадку, оцінкою предмета застави та оплатою послуг нотаріуса. Найменші додаткові видатки пропонують “Креді Агріколь Банк” і “Кристалбанк”. Шість з десяти банків готові враховувати непідтверджені доходи позичальників та не вимагають за них поручительства у третіх осіб.

За висновками фахівців, достатньо високі ставки з іпотеки зумовлені зниженням загальних обсягів кредитування в українських банках, що зробило обслуговування меншої кількості виданих кредитів більш дорогим. А падіння ставок за депозитами не компенсувало це зростання витрат, депозитні ставки все ще високі для нормального кредитування застав [5].

Новим підходом в іпотечному кредитуванні $\epsilon$ те, що банки, які надають іпотечні позики, реалізують спільні із забудовниками програми і за рахунок скидок від забудовників, надають за іпотечним кредитом більш низькі процентні ставки на частину періоду кредитування. Так, “Укргазбанк” у перший рік кредитування пропонує ставку $10 \%$, в наступні роки - 20-22\%; банк “Глобус" у перший рік - 5,99\%, в наступні роки - 20-21,9\%. Окрім цього, покупець зобов'язаний сплатити разову комісію - до 5\% суми кредиту, здійснити оцінку майна (приблизно 1500 грн) та застрахувати майно, яке купує у кредит, та власне життя. 
Елементи механізму іпотечного кредитування в українських банках *

\begin{tabular}{|c|c|c|c|c|c|c|}
\hline \multirow[b]{2}{*}{$\begin{array}{l}\text { Місце } \\
\text { в рей- } \\
\text { тингу }\end{array}$} & \multirow[b]{2}{*}{ Банки } & \multicolumn{3}{|c|}{ Фінансові умови: } & \multirow{2}{*}{\begin{tabular}{|c|} 
Враху- \\
вання \\
непід- \\
твер- \\
джених \\
доходів \\
\end{tabular}} & \multirow{2}{*}{$\begin{array}{c}\text { Обо- } \\
\text { в'язко- } \\
\text { ве } \\
\text { поручи- } \\
\text { тель- } \\
\text { ство } \\
\end{array}$} \\
\hline & & $\begin{array}{c}\text { Серед- } \\
\text { ньорічна } \\
\text { ефективна } \\
\text { ставка, \% }\end{array}$ & $\begin{array}{c}\text { Разова комісія } \\
\text { при видачі кре- } \\
\text { диту, у \% від } \\
\text { суми кредиту }\end{array}$ & $\begin{array}{l}\text { Додаткові видатки } \\
\text { при видачі кредиту }\end{array}$ & & \\
\hline 1 & “Кредобанк” & 22,60 & 0,00 & $\begin{array}{l}\text { Страхування застави, страху- } \\
\text { вання життя, оцінка предмета } \\
\text { застави }\end{array}$ & + & - \\
\hline 2 & "“Глобус” & 20,30 & 1,00 & Страхування застави & + & - \\
\hline 3 & “Укрсоцбанк” & 19,60 & 1,00 & $\begin{array}{l}\text { Страхування застави, страху- } \\
\text { вання життя, оцінка предмета } \\
\text { застави }\end{array}$ & + & + \\
\hline 4 & “"Ощадбанк” & 26,13 & 1,50 & $\begin{array}{l}\text { Страхування застави, страху- } \\
\text { вання життя, оцінка предмета } \\
\text { застави }\end{array}$ & - & - \\
\hline 5 & “Укргазбанк” & 25,78 & 1,00 & $\begin{array}{l}\text { Страхування застави, страху- } \\
\text { вання від нещасного випадку, } \\
\text { оцінка предмета застави }\end{array}$ & + & - \\
\hline 6 & $\begin{array}{l}\text { “Креді Агри- } \\
\text { коль Банк” }\end{array}$ & 28,10 & 2,50 & $\begin{array}{l}\text { Страхування застави, оцінка } \\
\text { предмета застави }\end{array}$ & + & - \\
\hline 7 & “Південний” & 30,47 & 1,50 & Послуги нотаріуса & - & + \\
\hline 8 & |“Кристалбанк” & 27,00 & 2,00 & $\begin{array}{l}\text { Страхування від нещасного } \\
\text { випадку }\end{array}$ & - & + \\
\hline 9 & “ТАСкомбанк” & 29,19 & 1,50 & $\begin{array}{l}\text { Страхування застави, страху- } \\
\text { вання життя }\end{array}$ & - & + \\
\hline 10 & “"ОПТ Банк” & 31,20 & 0,99 & $\begin{array}{l}\text { Страхування застави, страху- } \\
\text { вання від нещасного випадку, } \\
\text { оцінка предмета застави і по- } \\
\text { слуги нотаріуса }\end{array}$ & + & - \\
\hline
\end{tabular}

${ }^{*}$ Складено на основі [7].

у 2017 р. "Ощадбанк" започаткував програму іпотечного кредитування для вимушених переселенців строком до 30 років під 20\% річних. У “Піреус Банку" можна одержати такий іпотечний кредит на суму до $3 \mathrm{млн} \mathrm{грн,} \mathrm{строком} \mathrm{до} 15$ років за ставкою 19,9\% річних, з початковим внеском клієнта не менш ніж 50\% вартості житла.

В банку “Глобус" розроблена програма, до якої залучено банк, забудовника та покупця. Банк одержує процентні доходи, забудовник - реалізацію збудованого житла, а покупець - низьку ставку іпотечного кре- диту. Банк працює виключно з великими забудовниками з доброю репутацією, причому здійснює акредитацію кожного об'єкта, що будується. Конкретні ставки іпотеки, а також розмір початкового внеску залежать в кінцевому підсумку від забудовника, який надає скидки. На строк 1-3 роки банк встановлює пільговий період зі ставками 6-10\%. Такі підходи стимулюють позичальників до своєчасного і навіть передчасного погашення іпотеки.

Банк "Глобус" лояльно ставиться до своїх клієнтів, зокрема не вимагає додатко- 
вої застави, окрім житла, що будується; фрінансове поручительство береться лише від подружжя. При видачі кредиту не вимагає необов'язкових для клієнта платежів: плати за оцінку житла (адже банк працює на постійній основі із забудовниками і володіє інформацією про вартість квартир), оформлення страхування життя, майнових прав, від нещасного випадку. Процентна ставка за іпотечним кредитом залежить від початкового внеску: чим більший внесок, тим меншою є ставкам кредитування.

Проте загалом ставки в межах 20\% є занадто великими для українців, особливо в довгостроковій перспективі. За кордоном розрахункові ставки з іпотеки значно менші, зокрема: в Японії - 1,6-2,1\%, США 1,75-2,25\%, Великобританії - 2,0-2,5\%, Австралії - 6,0-6,5\%, країнах Шенген-зони 2,75-3,25\%, РФ - 9,25-9,75\% [8]. Процесу зниження процентних ставок перешкоджають чисельні випадки шахрайства з боку забудовників, які мали місце у вітчизняній практиці. Крім того, фракторами, які стримують розвиток іпотеки, є: значна частина проблемних кредитів, 30\% з яких становлять іпотечні кредити; неможливість вилучення та реалізації заставного майна у випадках неповернення позичальниками кредитів.

Слід зазначити, що конкуренція на ринку банківських послуг змушує банки застосовувати при роздрібному кредитуванні різноманітні програми лояльності, в межах яких клієнтам надають знижки до процентної ставки та/або одноразової комісії при виконанні певних умов, це, звичайно, роблять лише для власників зарплатних карток.

Окремого дослідження та поширення заслуговує досвід “Альфа-Банку”, який у 2017 p. Financial Club визнаний "Найбільш роздрібним банком"; у ньому досягнуто найбільший приріст гривневого кредитного портфелю фрізичних осіб (+1,38 млрд грн) [9]. Одним із елементів застосування клієн- тоорінтованої моделі роздрібного кредитування в цьому банкі $€$ те, що пропонуються зручні та різноманітні канали погашення кредитів: через термінали самообслуговування, у відділеннях “Укрпошти”, за допомогою квитанцій погашення "Альфа-Банку”, безпосередньо у відділеннях "Альфа-Банку”, через Інтернет в сервісі Альфа-Погашення або Інтернет-банкінг My Alfa-Bank, у банкоматах-терміналах та через будь-які інші банки України.

Значною мірою досягнення приросту кредитного портфелю в “Альфа-Банку” досягнуто за рахунок активізації маркетингу та реклами. Так, за 9 місяців 2017 р. банк витратив на такі цілі понад 100 млн грн або у 4 рази більше, ніж за аналогічний період попереднього року. Загалом приріст використання коштів на зазначені цілі загалом в українських банках становив 31\%. За темпами приросту коштів на рекламу лідерами стали “Укрбудінвестбанк” (+4897\%), “Кредит Європа Банк” (+1700\%), “Айбокс Банк” (+1209\%) [10]. Слід зазначити, що активізація рекламної діяльності банків свідчить про зміни у банківському маркетингу та менеджменті.

Достатньо новою у банківському обслуговуванні $€$ послуга партнерських продажів, тобто надання клієнтам можливості вибору пропозицій щодо роздрібних кредитів та порівняння умов кредитування у банках-партнерах. Так, у "Кредобанку" можна одержати інформацію щодо умов кредитування в “ОТП банку”, “ПУМБ”, “Приватбанку” та "Альфа-Банку”. Така послуга сприяє збільшенню довіри клієнтів до банківської установи, адже дає можливість для обґрунтованого вибору банку обслуговування на основі найбільш сприятливих умов кредитування.

Аналіз практики і тенденцій роздрібного банківського кредитування дає можливість виокремити такі елементи клієн- 
тоорієнтованих підходів у кредитуванні фізичних осіб:

- швидке реагування на попит громадян і пропонування нових банківських продуктів (кредити для вимушених переселенців, на здійснення енергоефективних заходів, на придбання вживаних автомобілів, беззаставні кредити готівкою тощо);

- створення особливих умов для "своїх” клієнтів, як складова загальної програми підвищення їх лояльності, надання їм кредитів за пільговими ставками;

- досягнення більшої прозорості умов кредитування шляхом розміщення на офіційних і партнерських Інтернет-ресурсах кредитних калькуляторів (для розрахунку щомісячних платежів, реальної процентної ставки та інших показників вибраного кредитного продукту);

- здійснення партнерських програм із кредитування з іншими банками, що збільшує довіру клієнтів та дає можливість вибрати оптимальні умови кредитування;

- спрощення умов кредитування готівкою, зокрема зменшення мінімального (18 років) та підвищення граничного віку позичальників (до 70 років), надання споживчих кредитів без довідок про доходи (ризики, які при цьому виникають, банк компенсує процентними ставками та комісійними);

- використання зручних і різноманітних каналів для погашення кредитів для створення клієнтам додаткових зручностей;

- впровадження спільних програм із компаніями-забудовниками житла, що дає можливість пропонувати більш низькі процентні ставки на частину періоду кредитування і сприяє розвитку іпотеки;

- впровадження спільних програм із торговими закладами, які продають товари тривалого використання, надання знижок при придбанні товарів в магазинах-партнерах і додаткових сервісних послуг;
- впровадження спільних програм 3 автодилерами, що дає змогу пропонувати кращі умови автокредитування і зменшувати ставки за кредитами;

- поширення послуги cashback, в межaх якої частина використаних клієнтом коштів повертається на його картковий рахунок та ін.

Звичайно, наявність клієнтоорієнтованих підходів у банківському обслуговуванні позитивно впливає на динаміку кредитування фізичних осіб, проте не слід нехтувати тим, що найбільш вагомими детермінантами, які сприяють вибору банку, є процентна ставка, умови кредитування, довіра до банку; менш важливими є - розташування банку, час розгляду заявки та рекомендації знайомих [11, с. 87].

Ми згідні з висновками фахівців, які вважають, що основними перешкодами для розвитку роздрібного кредитування слід вважати:

- збільшення прошарку незабезпечених верств громадян, що призводить до зменшення попиту на споживчі кредити;

- високий рівень процентних ставок, який не дає змоги використовувати споживчі кредити громадянам з низьким та середнім рівнями доходів;

- відмова потенційних позичальників від оформлення кредиту через невпевненість у стабільності власного фінансового становища;

- посилення вимог банків до позичальників, що зумовлює зростання вартості кредитних ресурсів для населення;

- низький рівень фінансової грамотності населення, який заважає позичальникам кваліфіковано вивчити умови кредитних договорів та ін. [11, с. 84].

Для закріплення позитивних тенденцій, які сформувалися у розвитку вітчизняної банківської системи, та подальшої активі- 
зації роздрібного банківського кредитування необхідно, на наш погляд, забезпечити:

- покращення макроекономічних параметрів функціонування економічної системи країни, що сприятиме підвищенню рівня життя громадян, збільшенню їх доходів, пожвавленню споживацького попиту;

- вдосконалення нормативної бази банківського кредитування з метою формування ефективних механізмів захисту прав позичальників і кредиторів;

- досягнення повної прозорості та зрозумілості умов кредитування для клієнтів, що сприятиме посиленню їхньої довіри до банку;

- збільшення строків кредитування, що можливе лише у випадку стабілізації соціально-економічного становища в країні;

- урізноманітнення продуктової лінійки, покращення сервісного обслуговування роздрібних клієнтів, зокрема через віддалені канали продажів;

- удосконалення маркетингових заходів і збільшення ресурсного забезпечення рекламних компаній;

- розширення партнерських відносин банків і торговельно-сервісних підприємств з метою запровадження партнерських програм кредитування із поліпшеними умовами (порівняно зі звичайними нецільовими картковими та готівковими кредитами);

- комплексне підвищення рівня фрінансової грамотності населення, що слід здійснювати, починаючи із дошкільних закладів і загальноосвітньої школи, продовжувати на рівні професійної та вищої освіти за допомогою різноманітних інструментів та усіх можливих інформаційних каналів.

Висновки. Основні проблеми, які перешкоджають розвитку кредитування населення, полягають у загалом нестабільній соціально-економічній ситуації, в
Україні. А це - висока інфляція, падіння реальних доходів громадян, низький рівень оплати праці переважної частин працюючих, безробіття і виїзд працездатного населення за кордон, політичні ризики та військові дії на сході країни, недовіра до банківських і фрінансових установ. Звичайно, такі процеси негативно позначаються на діяльності банків. Позитивні зрушення, які намітилися протягом останніх двох років у кредитуванні населення, свідчать про певну стабілізацію економічного становища, вони потребують глибокого вивчення, підтримки та стимулювання з боку держави. Крім того, пожвавлення ринку кредитування фрізичних осіб можна закріпити шляхом розвитку в банках клієнтоорієнтованих моделей обслуговування клієнтів, що сприятиме збільшенню їх лояльності, а в перспективі сприятиме зростанню рівня прибутковості банку.

Основою клієнтоорієнтованих підходів у роздрібному банківському кредитуванні мають бути: 1) врахування потреб клієнтів та пропозиція їм банківських продуктів, які відображають їх сучасні потреби (банківські установи мають працювати на випередження та пропонувати клієнтам послуги, які можуть задовольнити їх потреби у найближчому майбутньому); 2) покращення банківського обслуговування, розвиток дистанційних каналів продажів та їх диверсифікація, спрощення умов кредитування; 3) підвищення лояльності клієнтів банку, створення особливих умов для постійних клієнтів, застосування різноманітних стимулюючих інструментів у процесі кредитування; 4) забезпечення максимальної доступності та прозорості діяльності банків задля збільшення довіри клієнтів; 5) поширення партнерських програм щодо кредитування з іншими банками, компаніями-забудовниками житла, автодилерами, торговими закладами. 


\section{Список використаних джерел}

1. Основні показники діяльності банків / Національний банк України [Електронний ресурс]. Режим доступу : https://bank.gov.ua/control/uk/ publish/article?art_id=34661442 (дата звернення 1.12.2017).

2. Дослідження закредитованості населення України: 2016-2017: аналітичний звіт. Підготовлено GfK Ukraine на замовлення Financial Inclusion Project, WBG. 2017. - 135 c. [Електронний ресурс]. - Режим доступу : https://nabu. ua/images/tinymce/file/IFC_GfK_Over_ind_ukr_ v4.1\%20(1)(1).pdf.

3. Грошово-кредитна та фрінансова статистика. Серпень 2017 р. / Національний банк України. - К., 2017. - 14 с.

4. Закон України "Про споживче кредитування" від 15.11.2016 р. № 1734-VIII [Електронний ресурс]. - Режим доступу : http://zakon3. rada.gov.ua/.

5. Мінімальна ставка по кредитах готівкою на рік становить 5,55\% річних [Електронний ресурс]. - Режим доступу : http://www. bankchart.com.ua/.

6. 50 ведущих банков Украины. 2017. - К., 2017. - 60 c.

7. Вартість споживчих кредитів під заставу за рік зросла більш ніж на 5 в.п. [Електронний ресурс]. - Режим доступу : http://www. bankchart.com.ua/

8. Таблица ставок ипотечных кредитов в различных странах мира [Электронный ресурс]. - Режим доступа : http://www.reallook. com.ua/4659/tablica-stavok-ipotechnyx-kreditov-vraznyx-stranax-mira/ (дата звернення 4.12.2017).

9. Победитель в номинации “Самый розничный банк" [Электронный ресурс]. Режим доступа : http://banksrating.com.ua/ banks-of-the-year/pobeditel-v-nominatsii-samyjroznichnyj-bank/.

10. Які банки найбільше витрачаються на рекламу [Електронний ресурс]. - Режим доступу : https://minfin.com.ua/2017/12/06/31289319/.
11. Аликаева В.М. Кредитование фризических лиц коммерческими банками в Кабардино-Балкарской Республике: современное состояние / В.М. Аликаева, М.С. Оборин, T.A. Налчаджи, Т.Е. Гварлиани // Сервис в России и за рубежом. - 2017. - T. 11. - Вып. 5. C. 82-92.

\section{References}

1. Osnovni pokaznyky diialnosti bankiv [Basic indicators of banks]. Natsionalnyi bank Ukrainy National Bank of Ukraine. Available at: https://bank. gov.ua/control/uk/publish/article?art_id $=34661442$

2. Doslidzhennia zakredytovanosti naselennia Ukrainy: 2016-2017. Analitychnyi zvit. Pidhotovleno GfK Ukraine na zamovlennia Financial Inclusion Project, WBG. [Investigation of the crediting of the population of Ukraine: 2016-2017. Analytical report. Prepared by GfK Ukraine on request of the Financial Inclusion Project, WBG]. (2017). Available at: https://nabu.ua/images/tinymce/file/IFC_ GfK_Over_ind_ukr_v4.1\%20(1)(1).pdf

3. Hroshovo-kredytna ta finansova statystyka. Serpen 2017 r. [Monetary and financial statistics. August, 2017]. Natsionalnyi bank Ukrainy - National Bank of Ukraine. (2017). Kyiv [in Ukrainian].

4. Zakon Ukrainy "Pro spozhyvche kredytuvannia" vid 15.11.2016 r. № 1734-VIII [The Law of Ukraine "On consumer lending"]. (2016, November, 15). Available at: http://zakon3.rada.gov.ua/

5. Minimalna stavka po kredytakh hotivkoiu na rik stanovyt $5,55 \%$ richnykh [The minimum rate on cash loans per year is $5.55 \%$ per annum]. Available at: http://www.bankchart.com.ua/

6. 50 veduschih bankov Ukrainyi [The 50 leading banks of Ukraine]. (2017). Kyiv [in Russian].

7. Vartist spozhyvchykh kredytiv pid zastavu za rik zrosla bilsh nizh na 5 v.p [The cost of consumer loans collateral for the year increased by more than 5 pct.]. Available at: http://www.bankchart.com.ua/

8. Tablitsa stavok ipotechnyh kreditov $v$ razlichnyh stranah mira [Table of rates of mortgage loans in various countries of the world]. Available 
БАНКІВСЬКА СИСТЕМА I МОНЕТАРНА ПОЛІТИКА

at: http://www.reallook.com.ua/4659/tablica-stavokipotechnyx-kreditov-v-raznyx-stranax-mira/

9. Pobeditel $v$ nominatsii "Samyiy roznichnyiy bank" [The winner in the nomination "The most retail bank"]. Available at: http://banksrating.com.ua/ banks-of-the-year/pobeditel-v-nominatsii-samyjroznichnyj-bank/

10. Yaki banky naibilshe vytrachaiutsia na reklamu [Which banks are the most spent on advertising]. Available at: https://minfin.com. ua/2017/12/06/31289319/
11. Alikaeva, V.M., Oborin, M.S., Nalchadzhi, T.A., Gvarliani, T.E. (2017). Kreditovanie fizicheskih lits kommercheskimi bankami $v$ Kabardino-Balkarskoy Respublike: sovremennoe sostoyanie [Crediting of individuals by commercial banks in the Kabardino-Balkarian Republic: current status]. Servis $v$ Rossii i za rubezhom - Service in Russia and abroad, 5, 82-92. (Vol. 11) [in Russian].

Стаття надійшла до редакції 24.08.2017. 